\title{
Absorption and Assimilation of Foliarly Applied Urea in Tomato
}

\author{
Bernard A. L. Nicoulaud ${ }^{1}$ and Arnold J. Bloom ${ }^{2}$ \\ Department of Vegetable Crops, University of California, Davis, CA 95616
}

Additional index words. Lycopersicon esculentum, nitrogen fertilization

\begin{abstract}
In short-term experiments (10 days), urea applied foliarly as the sole $\mathrm{N}$ source promoted growth of ' $\mathrm{T}-5$ ' tomato (Lycopersicon esculentum Mill.) seedlings. The optimum urea concentration in the spray solution was $0.2 \%$ (w/w), and the best application frequency was once a day. Higher urea concentrations suppressed growth, producing severe leaf damage. The growth observed with foliar urea was less than that observed when inorganic $\mathbf{N}$ was supplied to the nutrient solution. Tomato seedlings absorbed $75 \%$ of the foliar applied urea within 12 hours and $99 \%$ within 24 hours after application. Urea concentrations in the plant tissues increased rapidly after foliar application. The maximum concentration was obtained in shoots at 12 hours and in roots at 24 hours after application. After that, concentration in the tissue declined to its original value within 48 hours. Tissue ammonium concentrations also increased after foliar application of urea. Shoot and root ammonium concentrations reached a maximum after 12 hours and stayed constant for the remainder of the 48-hour observation period. In the long-term experiment ( 5 weeks), the growth obtained with daily foliar applications of urea as the sole $\mathrm{N}$ source was only $10 \%$ of that when mineral $\mathrm{N}$ was available in the nutrient solution. Ammonium concentrations in the tissues of urea-treated plants were higher than those of plants treated with mineral $\mathrm{N}$ in the nutrient solution. Although urea concentrations were initially higher in plants treated with mineral $\mathbf{N}$, after 2 weeks urea concentrations declined in these plants and increased in the shoots of plants receiving foliar applications of urea. These results indicate 1) that urea applied foliarly can supply at least part of the $\mathbf{N}$ required to sustain growth; 2 ) that urea is absorbed and assimilated fast enough to alleviate $\mathrm{N}$ deprivation; and 3 ) that failure to promote rapid growth with foliar urea is probably due to phytotoxicity and not to $\mathbf{N}$ deprivation.
\end{abstract}

Although the use of foliarly applied urea as a $\mathrm{N}$ source is common (Below et al., 1985; Bowman and Paul, 1990, 1992; Vasilas et al., 1980), its physiological effects vary with cultivar (Peltonen, 1993) and season (Han et al., 1989; Ippersiel et al., 1989; Peltonen, 1993; Vasilas et al., 1980). Field experiments tend to be less consistent than greenhouse experiments in showing a beneficial effect of foliarly applied urea (Peltonen, 1993). In fieldgrown maize, the effects of the foliar sprays on shoot biomass, grain yield, and protein quality were not uniform (Ippersiel et al., 1989). The failure of foliar $\mathrm{N}$ applications to increase grain yields of maize may result when foliarly applied $\mathrm{N}$ is incorporated into a different pool of $\mathrm{N}$ than had been formed earlier by soil-derived $\mathrm{N}$ (Below et al., 1985). Foliar application of ${ }^{15} \mathrm{~N}$-urea (3.5\%) during fall on apple enhanced the retranslocation of leaf $\mathrm{N}$ to other plant parts and increased stored $\mathrm{N}$, thus enabling the plant to produce more growth during the following seasons (Han et al., 1989). In wheat, foliarly applied urea produced positive effects; these were attributed to higher leaf photosynthetic rates and higher leaf urease enzyme activities (Peltonen, 1993). When urea was foliarly applied to soybeans, yields were inconsistent depending on year and cultivar used (Vasilas et al., 1980).

Plants generally acquire $\mathrm{N}$ through root absorption of $\mathrm{NH}_{4}^{+}$or $\mathrm{NO}_{3}^{-}$from the soil solution, but, under certain circumstances, plants may obtain $\mathrm{N}$ from the atmosphere through the shoots. Shoots can gain $\mathrm{N}$ in the gaseous forms of $\mathrm{NH}_{3}$ and $\mathrm{NO}_{\mathrm{x}}$ (Marschner, 1995). Shoot uptake of dissolved $\mathrm{N}$ is a major source of $\mathrm{N}$

\footnotetext{
Received for publication 19 Dec. 1995. Accepted for publication 8 July 1996. This research was supported in part by a fellowship to B.A.L. Nicoulaud from the Brazilian agency CNPq-Conselho Nacional de Desenvolvimento Científico e Technológico Administraçao Central and by grants to A.J. Bloom including NSF IBN 93-06521 and USDA 93-37305-9143. The cost of publishing this paper was defrayed in part by the payment of page charges. Under postal regulations, this paper therefore must be hereby marked advertisement solely to indicate this fact. ${ }^{1}$ Current address: Fac. De Agronomia-UFRGS, Cx.P. 776, Porto Alegre-RS, 91.501-970, Brazil.

${ }^{2}$ To whom reprint requests should be addressed.
}

for epiphytes and carnivorous plants (Raven, 1988). For agricultural crops, urea, $\mathrm{NH}_{4}^{+}$, and $\mathrm{NO}_{3}{ }^{-}$are absorbed equally well when applied foliarly, but the first form is preferred because $\mathrm{NH}_{4}^{+}$and $\mathrm{NO}_{3}{ }^{-}$can cause unacceptable damage (Bowman and Paul, 1992). Perennial ryegrass turf, tall fescue, and creeping bentgrass turf rapidly absorbed $\mathrm{N}$ applied foliarly during the first $12 \mathrm{~h}$ after application, and old leaves absorbed more rapidly than new ones (Bowman and Paul, 1990, 1992). In maize, almost all of the urea applied foliarly was absorbed within $3 \mathrm{~d}$ (Ippersiel et al., 1989). Similar results were obtained with wheat, for which only $18 \%$ of the applied urea remained on leaf surfaces after $4 \mathrm{~h}$ and negligible amounts were found after $4 \mathrm{~d}$ (Smith et al., 1991).

The main objective of the following experiments was to ascertain if foliar urea applied as the sole $\mathrm{N}$ source can promote the growth of tomato plants and to determine the fate of this foliar urea. We conducted a series of short-term (10 d) experiments to determine the optimum foliar urea concentration and the extent of urea absorption and assimilation. In a subsequent long-term experiment (5 weeks), we monitored the effects of urea as well as changes in tissue urea and $\mathrm{NH}_{4}^{+}$levels in plants growing with foliar urea or with $\mathrm{NH}_{4} \mathrm{NO}_{3}$ in the nutrient medium.

\section{Materials and Methods}

' $\mathrm{T}-5$ ' tomato seeds (Lycopersicon esculentum) were obtained from Richard Jones, Dept. of Vegetable Crops, Univ. of California, Davis. 'T-5' is a fresh-market type and is a genotype with which we have extensive experience (Bloom, 1994). The seeds were germinated at room temperature in rolled paper toweling standing in $2 \mathrm{mMCaSO}_{4}$. After 1 week, seedlings were transplanted to 1.7-L opaque plastic containers, four to six plants per container. The containers were filled with a nutrient solution that consisted of micronutrients according to Epstein (1972): $2.0 \mathrm{mmol} \cdot \mathrm{L}^{-1} \mathrm{CaSO}_{4}$, $1.0 \mathrm{mmol} \cdot \mathrm{L}^{-1} \mathrm{MgSO}_{4}, 0.6 \mathrm{mmol} \cdot \mathrm{L}^{-1} \mathrm{~K}_{2} \mathrm{SO}_{4}, 1.0 \mathrm{mmol} \cdot \mathrm{L}^{-1} \mathrm{~K}_{2} \mathrm{HPO}_{4}$, and either $50 \mu \mathrm{mol} \cdot \mathrm{L}^{-1} \mathrm{NH}_{4} \mathrm{NO}_{3}$ or no $\mathrm{N}$ when foliar applications of urea were used. The nutrient solution was continuously aerated. 
Plants were grown for $2 \mathrm{~d}$ at moderate light intensity and then transferred to a greenhouse. The containers were immersed in a water bath that maintained root temperatures at $20 \pm 0.2^{\circ} \mathrm{C}$. Shoot temperatures varied between 25 and $35^{\circ} \mathrm{C}$. The greenhouse was furnished with supplemental $1000 \mathrm{~W}$ metal halide lamps to insure that light levels exceeded $1000 \mu \mathrm{mol} \cdot \mathrm{m}^{-2} \cdot \mathrm{s}^{-1}$ photosynthetically active radiation over a $14-\mathrm{h}$ day.

To determine the optimal urea concentration and frequency of application, two short-term (10-d) experiments were conducted. In the first experiment, plants were grown for 1 week with 50 $\mu \mathrm{mol} \cdot \mathrm{L}^{-1} \mathrm{NH}_{4} \mathrm{NO}_{3}$ in the nutrient solution, a concentration that can sustain the full growth of tomato (Smart and Bloom, 1993). The plants were transferred to a nutrient solution without $\mathrm{N}$ for $4 \mathrm{~d}$, and then received daily applications of urea solutions consisting of $0.0 \%, 0.1 \%, 0.2 \%$, or $0.3 \%(\mathrm{w} / \mathrm{w})$, which correspond to a concentration of 17,34 , or $51 \mathrm{mmol} \cdot \mathrm{L}^{-1}$, respectively. In the second experiment, the plants received the treatments immediately after being transferred to the greenhouse. The treatments in this experiment consisted of $0.0 \%$ or $0.2 \%(\mathrm{w} / \mathrm{w})$ applied daily, $0.1 \%(\mathrm{w} / \mathrm{w})$ applied twice a day, and $50 \mu \mathrm{mol} \cdot \mathrm{L}^{-1} \mathrm{NH}_{4} \mathrm{NO}_{3}$ in the nutrient solution.

The urea treatments were applied with a plant sprayer from Delta Industries. The surfactant $\alpha$-alkylaryl- $\Omega$-hydroxypoly (oxyethylene) glycol (Spray-Mate; National Chelating Corp.) was added to the urea solutions in the proportion of $0.3 \%(\mathrm{v} / \mathrm{v})$. The plants were sprayed until solution dripped off the leaves. To minimize urea leakage into the nutrient solution, a $4-\mathrm{cm}$ closedcell foam plug was fitted around the stem of each plant before the experiments and the nutrient solution was changed every day.

Before spraying the plants, daily samples of the nutrient solution were taken and analyzed for $\mathrm{NH}_{4}^{+}, \mathrm{NO}_{3}^{-}$, and urea as described below.

The plants were oven dried at $70^{\circ} \mathrm{C}$ and weighed at the end of the experiments. Tomato at these developmental stages shows exponential growth (Smart and Bloom, 1993) so that relative growth rate was calculated by the formula:

$R G R=\ln \left(W_{\text {final }} / W_{\text {initial }}\right) / t$

where $R G R$ is the relative growth rate $\left(\mathrm{g} \cdot \mathrm{g}^{-1} \cdot \mathrm{d}^{-1}\right), W_{\text {final }}$ is the plant fresh weight at the end of the experiment $(\mathrm{g}), W_{\text {initial }}$ is the plant fresh weight at the beginning of the experiment $(\mathrm{g})$, and $t$ is the duration of the experiment (d).

Urea absorption and assimilation was determined in two experiments. In a short-term experiment, plants were grown for 1 week in the greenhouse with $50 \mu \mathrm{mol} \cdot \mathrm{L}^{-1} \mathrm{NH}_{4} \mathrm{NO}_{3}$ in the nutrient solution and then transferred to nutrient solution without $\mathrm{N}$ for $4 \mathrm{~d}$. The plants then received foliar applications of $0.3 \%(\mathrm{v} / \mathrm{v}) \mathrm{surfac}-$ tant and either $0.0 \%$ or $0.25 \%$ (w/w) urea solutions as above. At time $0,4,12,24$, and $48 \mathrm{~h}$ after application, four plants in each treatment were used for urea uptake estimates. The shoots were submerged for $4 \mathrm{~min}$ in $100 \mathrm{~mL}$ of $1.0 \mathrm{mmol} \cdot \mathrm{L}^{-1} \mathrm{~K}_{2} \mathrm{HPO}_{4}$ adjusted to $\mathrm{pH}$ 7.0. This washing procedure optimized the amount of urea recovered from the leaves (recovery was $>95 \%$; data not shown). The washing solution was then analyzed for urea (Bowman and Paul, 1990). Plants were frozen in liquid N, freeze-dried, ground, and analyzed for levels of $\mathrm{NH}_{4}^{+}$and urea in the tissue.

In the long-term experiment, the plants received either daily foliar applications of $0.2 \%(\mathrm{w} / \mathrm{w})$ urea solution or $50 \mu \mathrm{mol} \cdot \mathrm{L}^{-1}$ $\mathrm{NH}_{4} \mathrm{NO}_{3}$ in the nutrient solution for 5 weeks. The containers received fresh nutrient solution every day to avoid nutrient solution contamination by urea. Six plants from each treatment were harvested every week, frozen in liquid N, freeze-dried, ground, and analyzed for tissue $\mathrm{NH}_{4}^{+}$and urea.

To determine $\mathrm{NO}_{3}^{-}, \mathrm{NH}_{4}^{+}$, or urea in plant tissues, the samples were extracted with $1.0 \mathrm{mmol} \cdot \mathrm{L}^{-1} \mathrm{CaSO}_{4}$. Nitrate was determined by high-performance (pressure) liquid chromatography (Thayer and Huffaker, 1980). The column was a $10-\mu \mathrm{m}$ anion-exchange column (no. 8165; Alltech) and the eluent was $35 \mathrm{~mm} \mathrm{KH_{2 }} \mathrm{PO}_{4}$ adjusted to $\mathrm{pH} 3.0$ with $\mathrm{H}_{3} \mathrm{PO}_{4}$. An autosampler (SIL-9A; Schimadzu) injected a $50-\mu \mathrm{L}$ sample, and the $\mathrm{NO}_{3}^{-}$eluting from the column was detected by absorption at $210 \mathrm{~nm}$. An integrator (CR501; Schimadzu) recorded peak heights. Ammonium was determined with an $\mathrm{NH}_{3}$-selective electrode (model 95-12; Orion). An autosampler (SIL-9A) injected $0.5-\mathrm{mL}$ sample into a background solution consisting of $10 \mu \mathrm{mol} \cdot \mathrm{L}^{-1} \mathrm{NH}_{4}^{+}$and $1 \mathrm{mmol} \cdot \mathrm{L}^{-1}$ $\mathrm{CaSO}_{4}$. The background solution and a solution containing 5.0 mol. $\mathrm{L}^{-1} \mathrm{KOH}$ (to bring the $\mathrm{pH}$ to above 12.0 , converting the $\mathrm{NH}_{4}^{+}$ to $\mathrm{NH}_{3}$ ) and $200 \mathrm{~mm}$ diethylenetriaminepentaacetic acid (DTPA, a chelator to prevent the precipitation of calcium compounds) were mixed in a 50:1 ratio before the combined streams flowed past the electrode. An integrator (CR501) recorded peak heights. Urea was analyzed by digestion of urea to $\mathrm{NH}_{4}^{+}$with urease (EC 3.5.1.5.; Sigma), and the $\mathrm{NH}_{4}^{+}$released was determined as described above.

Statistical analyses were performed with a one-way ANOVA (Microsoft Excel). A probability of $<5 \%$ was considered significant.

\section{Results}

Growth of tomatoes receiving daily foliar applications of urea as the sole $\mathrm{N}$ source varied significantly with concentration (Fig. 1). In these experiments, $\mathrm{NO}_{3}^{-}, \mathrm{NH}_{4}^{+}$, and urea in the nutrient solution without $\mathrm{N}$ were undetectable (below $10.0 \mu \mathrm{mol} \cdot \mathrm{L}^{-1}$ ). Optimal growth was obtained with $0.2 \%$ urea when the plants were grown either with $\mathrm{NH}_{4} \mathrm{NO}_{3}$ in the nutrient solution and then shifted to urea (Fig. 1) or with urea alone (Fig. 2). In the last case, there was no significant difference between $0.1 \%$ urea applied twice a day and $0.2 \%$ urea applied once a day (Fig. 2). The urea-treated plants grew significantly less than the ones receiving $\mathrm{NH}_{4} \mathrm{NO}_{3}$ in the nutrient solution.

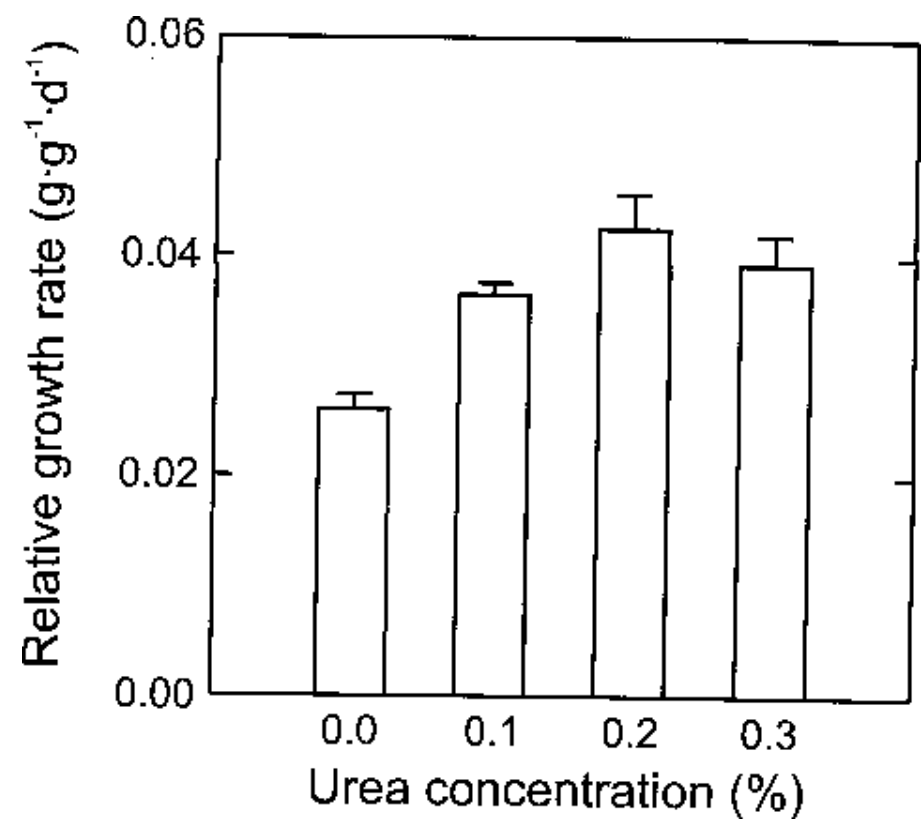

Fig. 1. Relative growth rate of 3-week-old tomato plants receiving different foliar applications of urea. Plants were grown with $50 \pm 10 \mu \mathrm{mol} \cdot \mathrm{L}^{-1} \mathrm{NH}_{4} \mathrm{NO}_{3}$ in the nutrient solution for 1 week, received a $\mathrm{N}$-free nutrient solution for $4 \mathrm{~d}$, and then received various concentrations of foliar urea as the sole $\mathrm{N}$ source plus a surfactant for the last $10 \mathrm{~d}$. Shown are the means \pm SE for six plants. 


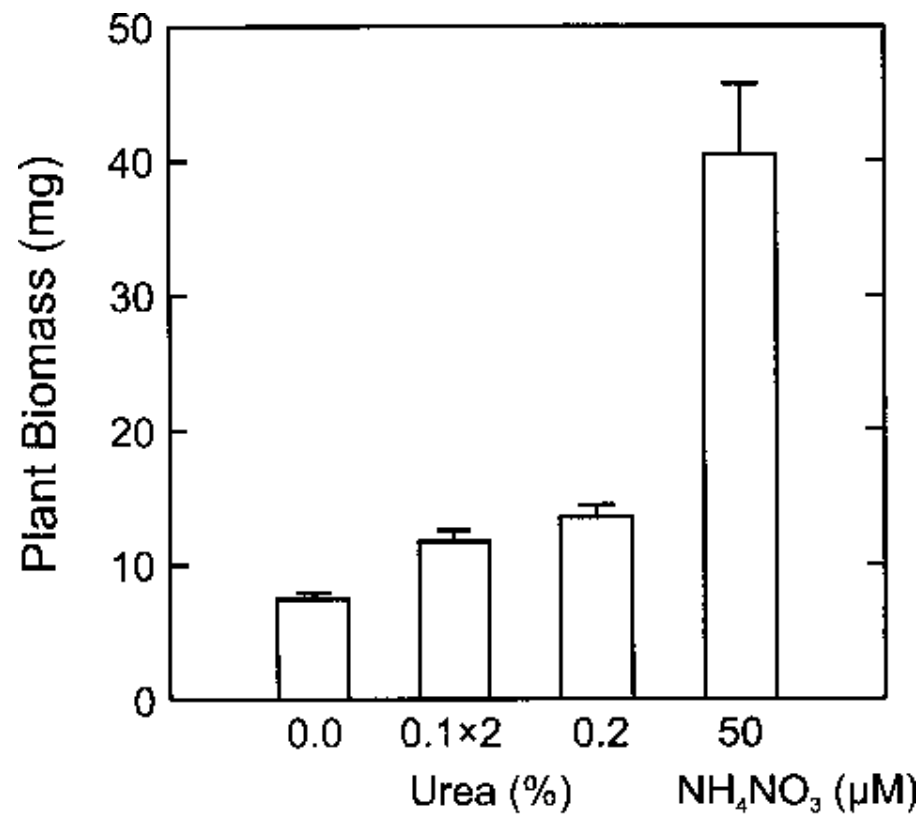

Fig. 2. Dry weight of 2-week-old tomato plants receiving either foliar application of urea or $50 \pm 10 \mu \mathrm{M} \mathrm{NH} \mathrm{NO}_{3}$ in the nutrient solution as the sole $\mathrm{N}$ source. In the $0.1 \times 2$ treatment, $0.1 \%$ urea $(\mathrm{w} / \mathrm{w})$ plus a surfactant was applied foliarly twice a day, whereas for the other treatments either $0.2 \%$ urea plus a surfactant or just a surfactant was applied once a day. Shown are the means \pm SE for six plants.

The amount of urea present on leaf surfaces decreased rapidly after application (Fig. 3A). After $24 \mathrm{~h}$, the amount of urea on the surface of urea-treated plants was similar to that of plants receiving only the surfactant. The urea concentration in the shoots of urea-treated plants increased during the first $12 \mathrm{~h}$ after urea application and then declined (Fig. 3B). With the exception of the initial readings $(0 \mathrm{~h})$, plants receiving the urea treatment had higher shoot urea levels than plants receiving only the surfactant (Fig. 3B). Root urea concentrations were highly variable and did not significantly differ between treatments (Fig. 3C). The $\mathrm{NH}_{4}^{+}$concentration of urea-treated plants also increased after application (Fig. $3 \mathrm{D}$ and E) and reached a maximum value after $12 \mathrm{~h}$. In contrast to the shoot urea concentration, the shoot $\mathrm{NH}_{4}^{+}$concentration remained constant for the remaining observation period (Fig. 3D). Tissue $\mathrm{NH}_{4}^{+}$concentration of urea-treated plants was always higher than that of plants receiving only the surfactant. $\mathrm{Root} \mathrm{NH}_{4}^{+}$concentrations in either treatment was higher than shoot $\mathrm{NH}_{4}{ }^{+}$concentrations (Fig. $3 \mathrm{D}$ and E).

In the long-term experiment, cumulative dry weight gain of plants grown with foliar application of urea as the sole $\mathrm{N}$ source was much smaller than that of plants grown with $\mathrm{NH}_{4} \mathrm{NO}_{3}$ in the nutrient

Fig. 3. Concentration on a dry mass basis of (A) urea on the leaf surfaces, (B) urea within shoot tissues, (C) urea within root tissues, (D) $\mathrm{NH}_{4}^{+}$within shoot tissues, and (E) $\mathrm{NH}_{4}^{+}$within root tissues for 3-week-old tomato plants sprayed with a solution that contained $0.25 \%$ (w/w) urea plus a surfactant (closed circles) or just a surfactant (open circles). The solution was applied at time zero. The plants had been grown for 1 week with $50 \mu \mathrm{mol} \cdot \mathrm{L}^{-1}$ $\mathrm{NH}_{4} \mathrm{NO}_{3}$ in the nutrient solution, then transferred to a $\mathrm{N}$-free solution for the $4 \mathrm{~d}$ before the onset of the experiment. Shown are the means \pm SE for four plants, with small error bars incorporated into the symbol. solution (Fig. 4A). Urea-grown plants had higher $\mathrm{NH}_{4}^{+}$concentrations in shoots and roots than those grown with $\mathrm{NH}_{4} \mathrm{NO}_{3}$ in the nutrient solution (Fig. 4B). During the first 2 weeks, shoot and root urea concentrations of the urea-grown plants were lower than those of plants grown with $\mathrm{NH}_{4} \mathrm{NO}_{3}$ in the nutrient solution, but, after this initial period, urea concentrations of the urea-grown plants became much higher than those of plants grown with $\mathrm{NH}_{4} \mathrm{NO}_{3}$ (Fig. 4C). Urea concentrations in shoots were very similar to those in roots for the $\mathrm{NH}_{4} \mathrm{NO}_{3}$-grown plants during the entire growth period, whereas after the second week, urea concentrations in roots were lower than those in shoots for the urea-grown plants (Fig. 4C).

\section{Discussion}

Urea applied daily to the leaves of tomato plants had a positive effect upon growth; $0.2 \%(\mathrm{w} / \mathrm{w})$ was the optimal concentration. The growth obtained with urea applications, however, was far less than that produced when $\mathrm{NH}_{4} \mathrm{NO}_{3}$ was available in the nutrient solution. Higher urea concentrations generally decreased growth because of excessive leaf damage. Leaf damage resulting from foliar application of urea has been reported previously when soybean leaves were treated with urea solutions of 2\% (Barel and Black, 1979) or 4\% (Krogmeier et al., 1989, 1991) and when wheat was treated with urea solutions of $11 \%$ (Peltonen, 1993). Leaf damage is the main factor that limits the total amount of $\mathrm{N}$ that can be supplied through foliar applications of urea. Understanding the causes of urea phytotoxicity is critical for improving the efficiency for this method of $\mathrm{N}$ supply.

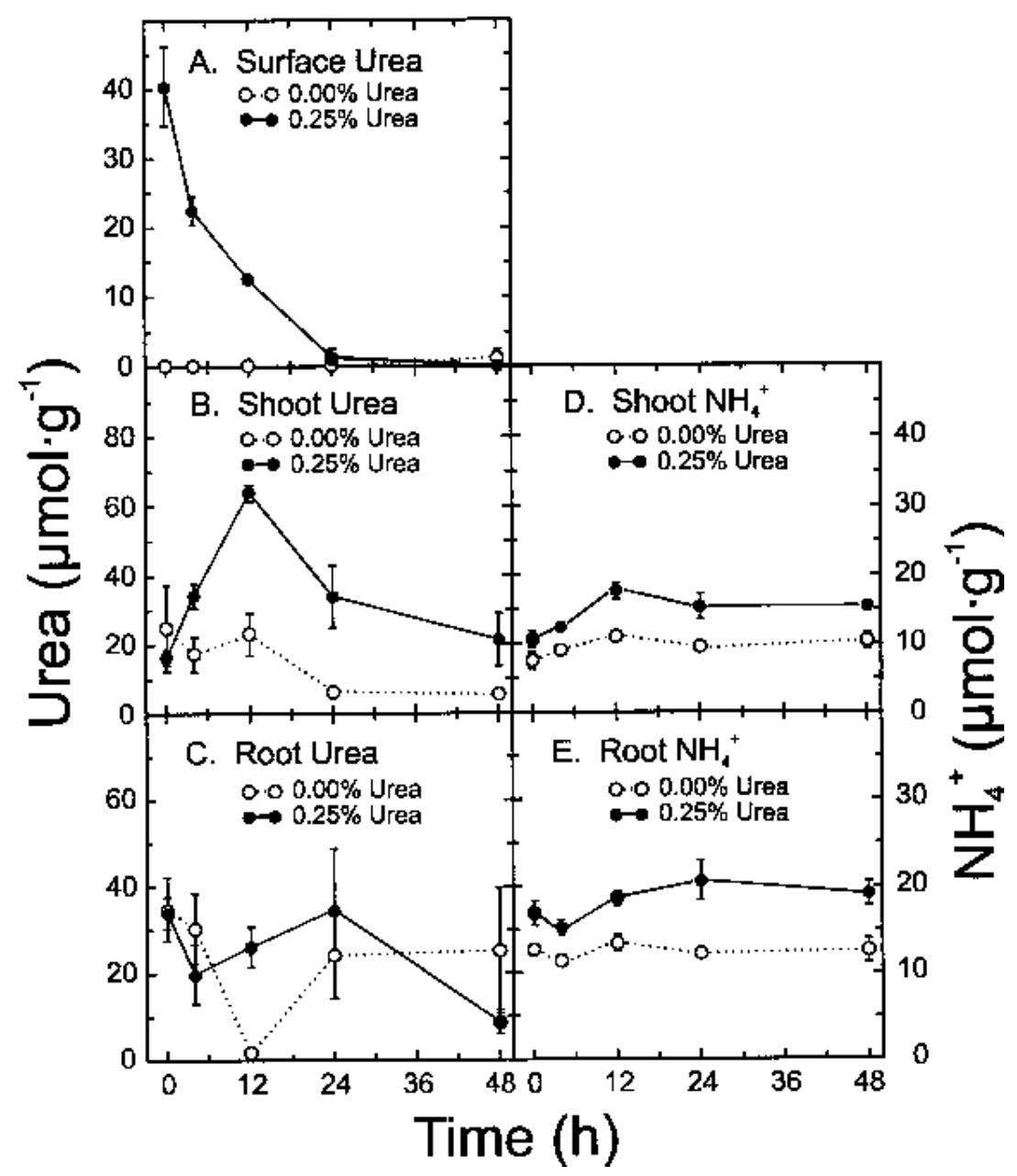




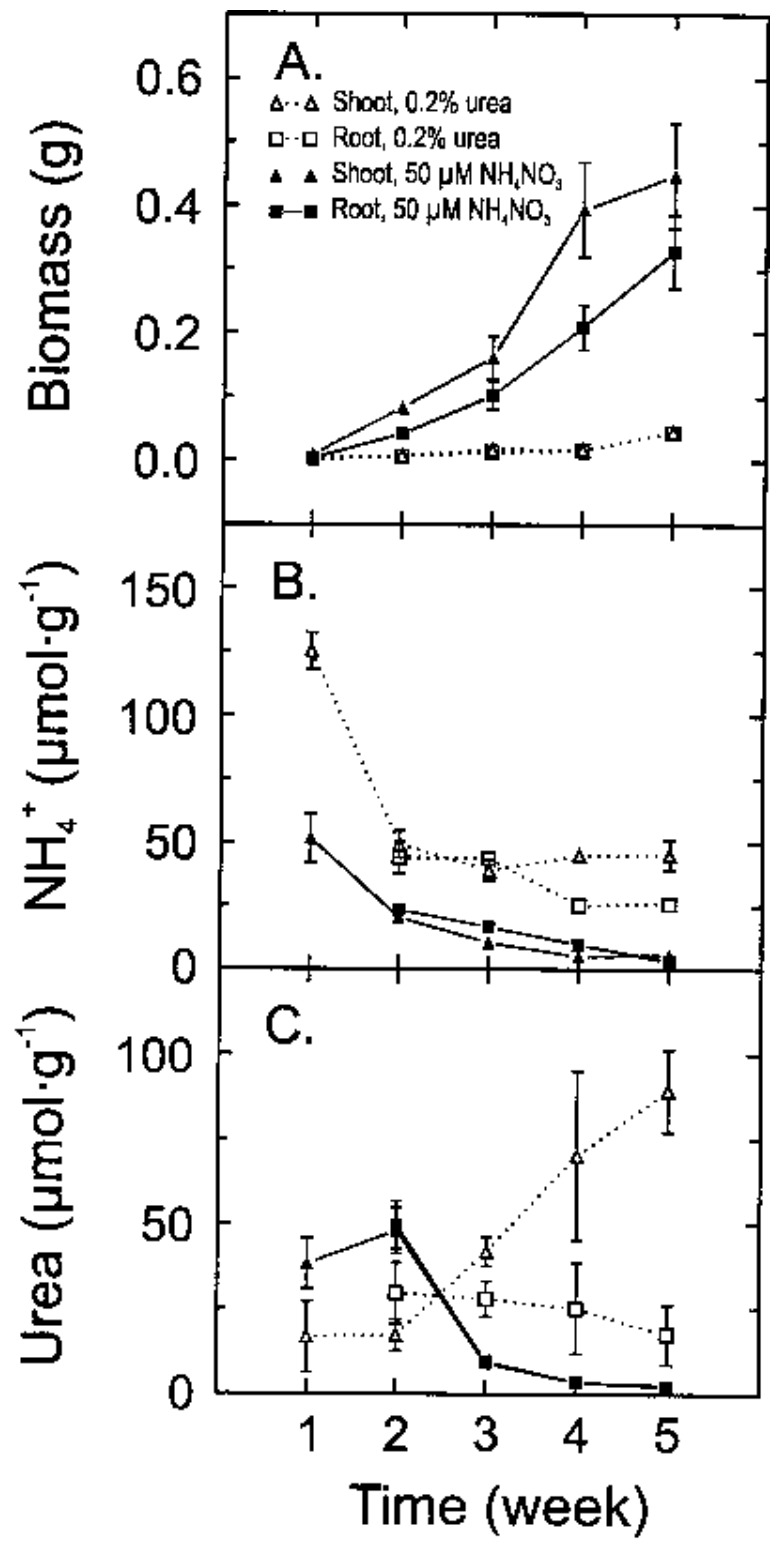

Fig. 4. On a dry mass basis, (A) Biomass, (B) $\mathrm{NH}_{4}^{+}$concentrations, and (C) urea concentrations in shoots (triangles) or roots (squares) of tomato plants grown for 5 weeks with either daily foliar applications of a $0.2 \%(\mathrm{w} / \mathrm{w})$ urea solution plus a surfactant (open symbols) or $50 \mu \mathrm{mol} \cdot \mathrm{L}^{-1} \mathrm{NH}_{4} \mathrm{NO}_{3}$ in the nutrient solution (closed symbols) as the sole $\mathrm{N}$ source. Shown are the means \pm sE for six plants, with small error bars incorporated into the symbols.

Here, tomato rapidly absorbed the foliar urea (Fig. 3A). This result is similar to that for soybeans in which leaves absorbed $71 \%$ of the urea applied within $18 \mathrm{~h}$ after application (Morris and Weaver, 1983) and to those for tall fescue, bentgrass, and perennial ryegrass (Bowman and Paul, 1990, 1992) in which most of urea applied foliarly was absorbed within $12 \mathrm{~h}$. Even faster uptake was measured for wheat at heading, in which only $18 \%$ of the $\mathrm{N}$ applied remained on the exterior of the leaves after $4 \mathrm{~h}$ (Smith et al. 1991). This result is consistent with the observation (Bowman and Paul, 1990) that old leaves absorbed urea at a higher rate than new leaves.

The washing method used here may overestimate urea absorption because it assumes that the urea absorbed equals the difference between the amount of urea present on the surface of the leaves at the time of application and that present after a certain time. Some authors (Morris and Weaver, 1983) have suggested that $\mathrm{N}$ can be lost from leaf surfaces by volatilization of ammonia. Nonetheless, the amount of $\mathrm{N}$ lost by ammonia volatilization after foliar urea application in wheat was only $0.32 \%$ of the $\mathrm{N}$ applied (Smith et al., 1991). Moreover, no significant differences were found among the washing method and two other methods for estimating leaf urea absorption after urea application (Bowman and Paul, 1990). These findings support that, although some small overestimation may occur, the washing method is a reasonable technique for estimating leaf urea uptake.

In the short-term experiments, foliar urea application caused a transient increase in the tissue urea concentrations. The same pattern of change in urea concentrations was observed in tall fescue and bentgrass (Bowman and Paul, 1990), perennial ryegrass (Bowman and Paul, 1992), and maize (Ippersiel et al., 1989). This transient increase was probably caused by rapid urea uptake, which increased the urea concentration, followed by rapid hydrolysis, which decreased it. As a result of rapid hydrolysis, plant $\mathrm{NH}_{4}^{+}$concentration increased after urea foliar application (Fig. 3 $\mathrm{D}$ and $\mathrm{E}$ ) as has been observed in other studies (Bowman and Paul, 1990, 1992). In contrast with urea concentrations, the $\mathrm{NH}_{4}{ }^{+}$concentrations remained high after their initial increase, up to $48 \mathrm{~h}$ after application. Whether these stable $\mathrm{NH}_{4}{ }^{+}$concentrations are caused by the continuous generation of $\mathrm{NH}_{4}^{+}$from urea hydrolysis or by an inhibition of $\mathrm{NH}_{4}^{+}$assimilation is unknown.

Results from the long-term experiment were similar to those of the short-term experiments in that plant growth was much smaller when foliar application of urea was the sole $\mathrm{N}$ source than when $\mathrm{NH}_{4} \mathrm{NO}_{3}$ was applied in the nutrient solution. Magalhaes and Wilcox (1983) obtained similar results, which they explained on the basis of the lower tissue $\mathrm{N}$ concentrations in the plants receiving foliar fertilization. Here plants grown with foliar applications of urea had higher $\mathrm{NH}_{4}{ }^{+}$concentrations than those grown with $\mathrm{NH}_{4} \mathrm{NO}_{3}$. The discrepancy between the two studies may derive from the use of different $\mathrm{N}$ concentrations in the nutrient solutions. Magalhaes and Wilcox (1983) used $8 \mathrm{mmol} \cdot \mathrm{L}^{-1}$ of either $\mathrm{NH}_{4}^{+}$or $\mathrm{NO}_{3}^{-}$, whereas we used a concentration of 50 $\mu \mathrm{mol} \cdot \mathrm{L}^{-1}$ ammonium nitrate, a concentration that can sustain the full growth of tomato (Smart and Bloom, 1993). Therefore, N deficiency is probably not the cause of slower growth under foliar application of urea.

A more probable cause of slower growth under foliar applications of urea is the accumulation of urea in the shoot tissues (Fig. 4C). Toxicity related to foliar application of urea has been reported for several species (Barel and Black, 1979; Krogmeier et al., 1989; 1991; Peltonen, 1993) and may be caused by the direct effects of urea or by $\mathrm{NH}_{4}^{+}$released by urease. Using phenylphosphorodiamidate to inhibit urease activity, Krogmeier et al. (1989) demonstrated that phytotoxicity was the direct effect of urea, rather than of $\mathrm{NH}_{4}^{+}$. This finding was supported by a subsequent experiment in which $\mathrm{Ni}$-deficient plants showed lower urease activity and more leaf-tip necrosis than $\mathrm{Ni}$-sufficient ones (Krogmeier et al., 1991). In wheat, leaf burn also increased with leaf urea content of the foliar spray (Peltonen, 1993). The reasons for urea toxicity are not known. Moreover, the high levels of $\mathrm{NH}_{4}^{+}$ present after urea was applied to the leaves (Figs. $3 \mathrm{D}$ and E and 4B) can also be, at least partly, responsible for inhibiting growth through feedback inhibition of urease activity. The tissue $\mathrm{NH}_{4}^{+}$ concentrations observed here are well below $350 \mu \mathrm{mol} \cdot \mathrm{g}^{-1}$ dry matter, the level at which tomato plants show severe symptoms of $\mathrm{NH}_{4}^{+}$toxicity (Barker and Corey, 1991)

Although urea applied to the leaves of tomato plants can promote growth, this growth is slower than that observed when $\mathrm{NH}_{4} \mathrm{NO}_{3}$ is applied to the nutrient solution. Slower growth is apparently the result of urea toxicity. 


\section{Literature Cited}

Barel, D. and C.A. Black. 1979. Effect of neutralization and addition of urea, sucrose, and various glycols on phosphorus absorption and leaf damage from foliar-applied phosphate. Plant Soil 52:515-525.

Barker, A.V. and K.A. Corey. 1991. Interrelations of ammonium toxicity and ethylene action in tomato. HortScience 26:177-180.

Below, F.E., S.J. Crafts-Brandner, J.E. Harper, and R.H. Hageman. 1985. Uptake, distribution, and remobilization of ${ }^{15} \mathrm{~N}$-labeled urea applied to maize canopies. Agron. J. 77:412-415.

Bloom, A.J. 1994 Crop acquisition of ammonium and nitrate, p. 303-310. In: K.J. Boote, J. M. Bennett, T.R. Sinclair, and G.M. Paulsen (eds.). Physiology and determination of crop yield. ASA, CSA, Madison, Wis.

Bowman, D.C. and J.L. Paul. 1990. The foliar absorption of urea-N by tall fescue and creeping bentgrass turf. J. Plant Nutr. 13:1095-1113.

Bowman, D.C. and J.L. Paul. 1992. Foliar absorption of urea, ammonium, and nitrate by perennial ryegrass turf. J. Amer. Soc. Hort. Sci. 117:7579.

Epstein, E. 1972. Mineral nutrition of plants: Principles and perspectives. Wiley, New York.

Han, Z., X. Zeng, and F. Wang. 1989. Effects of autumn foliar application of ${ }^{15} \mathrm{~N}$-urea on nitrogen storage and reuse in apple. J. Plant Nutr. 12:675685.

Ippersiel, D., I. Alli, F. MacKenzie, and G.R. Mehuys. 1989. Nitrogen distribution, yield, and quality of silage corn after foliar nitrogen fertilization. Agron. J. 81:783-786.

Krogmeier, M.J., G.W. McCarty, and J.M. Bremner. 1989. Phytotoxicity of foliar-applied urea. Proc. Natl. Acad. Sci. USA 21:8189-8191.
Krogmeier, M.J., G.W. McCarty, D.R. Shogren, and J.M. Bremner. 1991. Effect of nickel deficiency in soybeans on the phytotoxicity of foliarapplied urea. Plant Soil 135:283-286.

Magalhaes, J.R. and G.E. Wilcox. 1983. Tomato growth, nitrogen fraction and mineral composition in response to nitrate and ammonium foliar sprays. J. Plant Nutr. 6:911-939

Marschner, H. 1995. Mineral nutrition of higher plants. 2nd ed. Academic Press, London.

Morris, D.R. and R.W. Weaver. 1983. Absorption and translocation of foliarly applied ${ }^{15} \mathrm{~N}$ by soybeans. Agron. J. 75:572-574.

Peltonen, J. 1993. Interaction of late season foliar spray of urea and fungicide mixture in wheat production. J. Agron. Crop Sci. 170:296308.

Raven, J.A. 1988. Acquisition of nitrogen by the shoots of land plants: its occurrence and implications for acid-base regulation. New Phytol. 109:1-20.

Smart, D.R. and A.J. Bloom. 1993. Relationships between the kinetics of $\mathrm{NH}_{4}^{+}$and $\mathrm{NO}_{3}{ }^{-}$absorption and growth in the cultivated tomato (Lycopersicon esculentum Mill. cv T-5). Plant Cell Environ. 16:259-267.

Smith, C.J., J.R. Freney, R.R. Sherlock, and I.E. Galbally. 1991. The fate of urea nitrogen applied in a foliar spray to wheat at heading. Fert. Res. 28:129-138.

Thayer, J.R. and R.C. Huffaker. 1980. Determination of nitrate and nitrite by high-pressure liquid chromatography: Comparison with other methods for nitrate determination. Anal. Biochem. 102:110-119.

Vasilas, B.L., J.O. Leeg, and D.C. Wolf. 1980. Foliar fertilization of soybeans: Absorption and translocation of ${ }^{15} \mathrm{~N}$-labeled urea. Agron. J. 72:271-275. 